\title{
Sports or Fine Arts? Investigation of Free Time Management Skills of Participants Interested in Sports and Fine Arts
}

\author{
Osman Gumusgul (Corresponding author) \\ School of Physical Education and Sports, Dumlupinar University \\ Germiyan Kampusu, Afyon Yolu, Kutahya, Turkey
}

Tel: 90-274-227-0458Ｅ-mail: osmangumusgul@gmail.com

\author{
Received: February 1, 2019 Accepted: March 2, 2019 Published: March 7, 2019 \\ doi:10.5296/jei.v5i1.14293 URL: https://doi.org/10.5296/jei.v5i1.14293
}

\begin{abstract}
In this study it was aimed to investigate free time management skills of participants interested in sports and fine arts. 233 students studying at School of Physical Education and Sports and Faculty of Fine Arts took part in this research. Data was gathered through Free Time Management Scale that had been developed by Wang et al. (2011) and translated to Turkish Language by Akgul and Karakucuk (2015). In evaluation part, descriptive statistical analysis and Manova test was used. It was statistically determined that there were significant differences on free time management scores between participants interested in sports and participants interested in fine arts. Also there were significant differences on free time activities while there were not significant differences on genders. According to the results participants interested in sports have higher scores in goal setting and technique and evaluating sub-dimensions and participants interested in fine arts have higher scores in free time attitudes and scheduling sub dimensions.
\end{abstract}

Keywords: Free time management, Sports, Fine arts

\section{Introduction}

Defining concept of time is one of the most difficult phenomena and nowadays there has been different definitions about this concept, which people especially focus on (Ustun, 2013). We can define time as the way of perceiving or passing the time needed to do a particular job or the occurrence of events that occurred one after the other (Gurbuz \& Aydin, 2012).

Time cannot be collected like money, stored like raw material, cannot be served as a cake, it cannot be stopped like a vehicle and it cannot be used as a commodity and it cannot be used 
in any way. In certain limits, we can replace one source with another, for example, we can use machines instead of manpower. However, there is no other source to replace time. It can therefore be called life equals time. Time wasting means wasting life (Adair, 2006; Akgul \& Karakucuk, 2015).

Leisure time is defined as the period not spent for sleeping, eating, and doing other compulsory jobs for the individual (Ayhan et al., 2018). This time, which one can freely use for participation in recreational activities, must be outside of work time and compulsory needs (Demirel \& Harmandar, 2009). Karakucuk summarizes this situation in the following sentence: "One may think that leisure time is similar to a sword with two sharp edges." If used positively, it may contribute to personal and social improvement; if used negatively, it may result in problems such as lack of discipline (Karakucuk, 2008).

Free time provides the best opportunity for people to pursue pleasure, happiness, and self-expression. However, rather than using their free time in a healthy and constructive way, many individuals spend their free time without planning. Such free time usually involves killing time and avoiding boredom. A lack of planning can create problems such as boredom and an unhealthy sedentary lifestyle. As mentioned, free time is regarded as the period of unobligated time during which individuals can decide what to do. It is usually spent in leisure pursuits in order to relax after experiencing stress or to improve one's health. Various benefits have been associated with leisure (Robinson \& Godbey, 1999).

Benefits with leisure affect several aspects of life, including physical health, and psychological, social, and economic well-being. Additionally, leisure may be important in helping people maintain or improve their health because it counteracts the negative effects of stress on physical and mental health (Driver et al., 1991).

Lack of leisure skills or the ability to manage leisure time can cause to be bored (Hickerson $\&$ Beggs, 2007). Also having no idea of how to use free time probably results in an unhealthy sedentary lifestyle (Federov, 2005). Spending time without planning may make individuals feel rushed because their time is not well organized and allocated (Buckworth \& Nigg, 2004)

Individuals' need for leisure has started to take precedence over their regular daily activities. Leisure activities are a part of individuals' lives now and they are mentioned and associated with the individuals who pursue them. This approach causes conflicts between leisure activities and responsibilities of daily life. Daily activities are defined as the activities that individuals are obliged to do in order to continue their work or study lives or their existence in general (Isik \& Demirel, 2018).

Like many other limited resources, time, as limited resource, can be more or less effectively managed (Stebbins, 2016). The concept of time, which is effective at every stage of life, is beginning to affect education profoundly (Gumusgul, 2018).

Time management is the task of ensuring the flow of everyday life, controlling events and controlling events by managing oneself. It would not be wrong to say that the process of making management functions such as planning, organizing, executing and auditing suitable for its own program in order to reach the goals that the individual has in his / her job and 
social life (Gozel, 2010; Ari, 2017).

Time management helps individuals to establish and separate the academic tasks from those in everyday life. They achieve their goals and thus overcome the obstacles inherent in any field. Moreover, it forms a system of rational, disciplined conduct, to act successfully and in time, to capitalize on opportunities, to use control over the personal psychic, to acquire a sense of fulfilment, to evaluate the progress, and last but not least, to maintain excellent relationships in academia, family and society. However, it cannot be planned all the time, because we shall accept that there are events that do not depend on us (Frasineanu, 2018).

Art and sports have been present in almost every civilization from prehistoric times to the present day in parallel with social, cultural, political and economic developments and changes. However, it was not easy to talk about a direct visible relationship between the two. In such a way that a person's health depends on the integrity of the soul and body, art and sports are spreading to all times and places, including all the activities of human beings in social life and there is a wide scope (Yilmaz, 2018).

As a type of music or painting is the subject of mass interest, it is a prerequisite for the sport to be adopted and spread throughout the society. It is caused by adoration, coming to the eye, calling out to the senses and in one aspect by envy (Erkut, 1999).

People have spent more time in art, sports and people with the settled life and technology development. The efforts to evaluate free time have led to the development of sport and art. It can be said that art and sport that appear to be two different subjects contribute to physical and spiritual development. In sport, there is an amateur effort in art. Both branches are an indispensable social need for the international promotion and international relations of the country (Tanyeri, 2010).

\section{Method}

In material and method part, demographic information of participants, variables of study, gathering tool and statistical methods applied to the data were discussed.

\subsection{Model of Research}

The study has been carried out on the basis of quantitative research design. The study is suitable for the relational scanning model that is one of the general scanning models for defining to determine the relationship between research variables, which is the general scanning model is made to scan on the universe of all or a sample taken from it to reach a general judgment about universe at a stage consisting of a plurality of elements (Karasar, 2012; Isik, 2018).

\subsection{Participants}

233 students selected randomly studying at School of Physical Education and Sports and Faculty of Fine Arts took part in this research. Demographic features of participants are pointed out at Table 1 . 
Table 1. Demographic features of participants

\begin{tabular}{|l|l|l|l|}
\hline Factor & Variable & $\mathbf{N}$ & \% \\
\hline \multirow{4}{*}{ Gender } & Male & 127 & 54.5 \\
\cline { 2 - 4 } & Female & 106 & 45.5 \\
\hline \multirow{4}{*}{ Age } & 20 years old and younger & 63 & 27 \\
\cline { 2 - 4 } & $21-23$ years old & 120 & 51.5 \\
\cline { 2 - 4 } & 24 years old and older & 50 & 21.5 \\
\hline \multirow{5}{*}{ Activity on Free Time } & Physical Education and Sports & 120 & 51.5 \\
\cline { 2 - 4 } & Fine Arts & 113 & 48.5 \\
\hline \multirow{5}{*}{ Academic Success(on 4.00) } & Physical Activities & 81 & 34.8 \\
\cline { 2 - 4 } & Social Activies & 90 & 38.6 \\
\cline { 2 - 4 } & Cultural/Art Activity & 62 & 26.6 \\
\cline { 2 - 4 } & 2.00 and less & 40 & 17.2 \\
\cline { 2 - 4 } & $2.01-2.50$ & 79 & 33.9 \\
\cline { 2 - 4 } & $2.51-3.00$ & 71 & 30.5 \\
\cline { 2 - 4 } & $3.51-4.00$ & 43 & 18.5 \\
\hline
\end{tabular}

\subsection{Data Collection Tools}

Free Time Management Scale that had been developed by Wang et al. (2011) and translated to Turkish Language by Akgul and Karakucuk (2015) was applied.

Free time management scale was developed by Wang et al. (2011) and translated to Turkish Language by Akgul and Karakucuk (2015). The scale consists of 15 items and 4 dimensions being "Goal setting and technique" (5 items), "Free time attitudes" (3 items), "evaluating" (4 items) and "Scheduling" ( 3 items). The answer codes to be given for each item differ between 1.00 and 5.00. Grading items in the scale are as follows: Strongly agree (5), agree (4), neutral (3), disagree (2), strongly disagree (1).

\subsection{Data Analaysis}

In evaluation part, Kurtosis and Skewness values were determined and descriptive statistical analysis and Manova test were used.

\section{Findings}

Free time management scale was developed by Wang et al. (2011) and translated to Turkish Language by Akgul and Karakucuk (2015). The scale consists of 15 items and 4 dimensions being "Goal setting and technique" (5 items), "Free time attitudes" (3 items), "evaluating" (4 items) and "Scheduling" ( 3 items). The answer codes to be given for each item differ between 1.00 and 5.00. Grading items in the scale are as follows: Strongly agree (5), agree (4), Neutral 
(3), disagree (2), strongly disagree (1).

Table 2. Free time management scores according to gender

\begin{tabular}{|c|c|c|c|c|c|c|c|}
\hline Subdimensions & Gender & $\mathbf{n}$ & $\mathbf{X}$ & $\mathbf{S}$ & SD & $\mathbf{F}$ & $\mathbf{p}$ \\
\hline \multirow{2}{*}{ Goal Setting and Technique } & Male & 127 & 20.54 & 0.476 & \multirow{2}{*}{$1-230$} & \multirow{2}{*}{0.558} & \multirow{2}{*}{0.456} \\
\hline & Female & 106 & 18.02 & 0.524 & & & \\
\hline \multirow{2}{*}{ Evaluating } & Male & 127 & 10.92 & 0.382 & \multirow{2}{*}{$1-230$} & \multirow{2}{*}{0.529} & \multirow{2}{*}{0.468} \\
\hline & Female & 106 & 10.28 & 0.420 & & & \\
\hline \multirow{2}{*}{ Free time attitudes } & Male & 127 & 12.04 & 0.245 & \multirow{2}{*}{$1-230$} & \multirow{2}{*}{0.252} & \multirow{2}{*}{0.616} \\
\hline & Female & 106 & 12.14 & 0.269 & & & \\
\hline \multirow{2}{*}{ Scheduling } & Male & 127 & 7.78 & 0.243 & \multirow{2}{*}{$1-230$} & \multirow{2}{*}{0.079} & \multirow{2}{*}{0.779} \\
\hline & Female & 106 & 8.16 & 0.268 & & & \\
\hline
\end{tabular}

The results of MANOVA test on the sub-dimensions of Free Time Management Scale points that there is no significant difference between male and female participants in terms of free time management sub-dimensions (WilksL $(\lambda)=.995 ; \mathrm{F}(4.227)=.275 ; \mathrm{p}>0.05)$. This finding indicates that the scores to be obtained from the linear component consisting of sub-dimension scores do not change depending on gender. Mean and standard deviation values of the scale and One-way ANOVA results of the sub-dimension according to the gender were shown in the table.

Table 3. Free time management scores according to interests of participants

\begin{tabular}{|c|c|c|c|c|c|c|c|}
\hline Subdimensions & Interest & $\mathbf{n}$ & $\mathbf{X}$ & $\mathbf{S}$ & SD & $\mathbf{F}$ & $\mathbf{p}$ \\
\hline \multirow{2}{*}{ Goal Setting and Technique } & Sports & 120 & 20.54 & 0.477 & \multirow{2}{*}{$1-230$} & \multirow{2}{*}{13.430} & \multirow{2}{*}{0.000} \\
\hline & Fine Arts & 113 & 18.02 & 0.493 & & & \\
\hline \multirow{2}{*}{ Evaluating } & Sports & 120 & 10.92 & 0.392 & \multirow{2}{*}{$1-230$} & \multirow{2}{*}{1.283} & \multirow{2}{*}{0.259} \\
\hline & Fine Arts & 113 & 10.28 & 0.406 & & & \\
\hline \multirow{2}{*}{ Free time attitudes } & Sports & 120 & 12.04 & 0.252 & \multirow{2}{*}{$1-230$} & \multirow{2}{*}{0.252} & \multirow{2}{*}{0.781} \\
\hline & Fine Arts & 113 & 12.14 & 0.261 & & & \\
\hline \multirow{2}{*}{ Scheduling } & Sports & 120 & 7.78 & 0.250 & \multirow{2}{*}{$1-230$} & \multirow{2}{*}{0.079} & \multirow{2}{*}{0.283} \\
\hline & Fine Arts & 113 & 8.17 & 0.258 & & & \\
\hline
\end{tabular}

The results of MANOVA test on the sub-dimensions of Free Time Management Scale show that the participants differ significantly in terms of the sub-dimensions of free time 
management scale according to the areas of interest $(\operatorname{WilksL}(\lambda)=.008 ; \mathrm{F}(4.227)=3.512 ; \mathrm{p}<$ 0.05). This finding indicates that scores obtained from the linear component of the sub-dimension scores vary depending on the area of interest. Mean and standard deviation values of the scale and One-way ANOVA results of sub-dimension based on the definitions of the participants were shown in the table.

Table 4. Free time management scores according to activity at free time

\begin{tabular}{|c|c|c|c|c|c|c|c|c|}
\hline Subdimensions & Free Time Activity & $\mathbf{n}$ & $\mathbf{x}$ & S & SD & $\mathbf{F}$ & $\mathbf{p}$ & Fark \\
\hline \multirow{3}{*}{ Goal Setting and Technique } & Physical Activities & 81 & 20.81 & 0.580 & \multirow{3}{*}{$2-229$} & \multirow{3}{*}{7.339} & \multirow{3}{*}{0.001} & \multirow{3}{*}{$1-3$} \\
\hline & Social Activities & 90 & 19.27 & 0.550 & & & & \\
\hline & Cultural/Art Activity & 62 & 17.42 & 0.668 & & & & \\
\hline \multirow{3}{*}{ Evaluating } & Physical Activities & 81 & 11.23 & 0.477 & \multirow{3}{*}{$2-229$} & \multirow{3}{*}{0.227} & \multirow{3}{*}{0.227} & \\
\hline & Social Activities & 90 & 10.46 & 0.452 & & & & \\
\hline & Cultural/Art Activity & 62 & 10.01 & 0.549 & & & & \\
\hline \multirow{3}{*}{ Free time attitudes } & Physical Activities & 81 & 12.30 & 0.307 & \multirow{3}{*}{$2-229$} & \multirow{3}{*}{0.645} & \multirow{3}{*}{0.645} & \\
\hline & Social Activities & 90 & 12.03 & 0.291 & & & & \\
\hline & Cultural/Art Activity & 62 & 11.88 & 0.354 & & & & \\
\hline \multirow{3}{*}{ Scheduling } & Physical Activities & 81 & 7.61 & 0.304 & \multirow{3}{*}{$2-229$} & \multirow{3}{*}{0.301} & \multirow{3}{*}{0.301} & \\
\hline & Social Activities & 90 & 8.26 & 0.288 & & & & \\
\hline & Cultural/Art Activity & 62 & 8.00 & 0.350 & & & & \\
\hline
\end{tabular}

The results of MANOVA test on the sub-dimensions of the Free Time Management Scale revealed that participants differed significantly in terms of their sub-dimensions according The activities they participate at their free time (WilksL $(\lambda)=.2,091 ; \mathrm{F}(12.219)=.2,091 ; \mathrm{p}<$ 0.05). This finding indicates that the scores to be obtained from the linear component consisting of sub-dimension scores change depending on the type of activity they participate. Mean and standard deviation values of the scale for four factors and One-way ANOVA results of the sub-dimension based on the free time management of the participants are shown in the table. According to Tukey HSD test, mean of participants who prefer physical activities in goal setting and technique sub-dimension $(X=20.81 \pm 4.94)$ has higher average score than participants who prefer cultural/art activities $(X=17.42 \pm 5.39)$.

\section{Conclusion}

It was aimed to investigate free time management skills of participants interested in sports and fine arts in this study. Physical activities and cultural, art activities can be called between most common free time activities. It was determined that participants interested in physical activities have higher goal setting and technique skills than participants interested in fine arts. Goal setting in sports can increase the quality of the work by increasing the motivation of 
athletes since it will reveal clearly what is expected from an athlete. It guides to improve the performance of the athlete. Supporting this research Barut (2018) found that individuals who practiced physical activities for longer time had higher goal settings scores. With free time evaluating, participants who are interested in sports have higher scores than participants who are interested in fine arts. Physical activities may need more planning for breaks during activities. Also sports can give a discipline to athletes and these disciplines can cause better free time evaluating. Thanks to this discipline athletes or physical activity participants save free time during daily life. On their study, Akyuz (2015) determined that physical activity participants have higher scores at free time evaluating than the others. Cognitive part of the study showed that participants interested in fine arts had higher scores at free time attitudes sub dimension. It can be thought this situation has been caused by the fact that participants interested in fine arts thinks free time is important and good use of free time can cause happiness. Even though there was not significantly difference, participants had higher scores at scheduling than participants interested in physical activity. According to the study of Gould and Carson (2008), life skills can have development through sport.

According to statistical analyses there was not statistically significant difference between free time management and gender. Even though at goal setting and technique, evaluating and scheduling sub dimensions male participants scores were higher, it was not determined significantly difference. Opposite to this research, Alay (2003), Eldeleklioglu (2008), and Gumusgul (2013) found that there was significant different between time management and gender and Serdar et al. (2017) found that there was significant different between free time management and gender. Misra and McKean (2000), and Razali et al. (2018) emphasized at their studies that there were significantly differences between gender and time management.

The results of the study indicated that there was statistically significant difference between free time management and free time activities of participants. Participants who prefer physical activities at their free time have more free time management skills than participants who prefer social, cultural and art activities. Except of scheduling sub dimension participants who are interested in physical activity has higher scores than other free time activities. The reason can be thought, individuals prefer physical activity at their free time can gain aim setting skills and create new techniques at organizing free time. Macquet (2010) showed that time management was a key factor in allowing athletes to be fit and perform well in sports competitions and academic exams. Time management was also shown to be a key factor in achieving positive outcomes during phase transitions throughout the sports career, such as preparing for retirement from the sports career while still competing at world-class level (Lavalee \& Robinson, 2007), starting an international career while studying to prepare for a job (Stambulova et al., 2012).

In the light of the results of the study, it can be seen as a short cut to individuals' happiness reach the desired result without forcing by motivating themselves to participate any of fine arts, social or physical activities. Inactive life style is unhealthy for human comparing with a life with any of these activities. 


\section{References}

Adair, J. (2006). In O. Çolakoğlu (Trans.), Etkili zaman yonetimi. Istanbul: Babiali Kultur.

Akgul, B. M., \& Karakucuk, S. (2015). Free time management scale: Validity and reliability analysis. Journal of Human Sciences, 12(2), 1867-1880. https://doi.org/10.14687/ijhs. v12i2.3445

Akyuz, H. (2015). Investigation of university students' attitudes towards leisure time activities: Bartin university sample (Master Thesis, Bartin University, Bartin).

Ari, C. (2017). Pedagojik formasyonda kayıtlı öğretmen adaylarının boş zaman yönetimleri ve yaşam kaliteleri arasındaki ilişkinin incelenmesi. Yüksek Lisans Tezi, Ankara: Ankara Yıldırım Beyazıt Üniversitesi.

Ayhan, C., Ekinci, N. E., Yalcin, I., \& Yigit, Ş. (2018). Investigation of constraints that occur during participation in leisure activities by high school students: A sample of Turkey. Education Sciences, 8(2), 86. https://doi.org/10.3390/educsci8020086

Barut, A. İ. (2018). Comparison of perceived leadership behavior and coaching behavior assessment on uni-league men basketballers have different goal orientations (PhD Thesis, Mersin University, Mersin, Turkey).

Buckworth, J., \& Nigg, C. (2004). Physical activity, exercise, and sedentary behavior in college students. Journal of American College Health, 53(1), 28-34. https://doi.org/10.3200/ JACH.53.1.28-34

Demirel, M., \& Harmandar, D. (2009). Universite ogrencilerinin rekreasyonel etkinliklere katilimlarinda engel olusturabilecek faktorlerin belirlenmesi. Uluslararası Insan Bilimleri Dergisi, 6, 839-846.

Driver, B. L., Brown, P. J., \& Peterson, G. L. (1991). Leisure benefits. PA: Venture.

Eldeleklioğlu, J. (2008). Investigation of adolescents' time management skills in terms of anxiety, age and gender variables. Elementary Education Online, 7(3), 656-663.

Erkut, V. (1999). Sanat ve insan. Ankara: Timas Yayinlari.

Fedorov, A. V. (2005). School students and computer games with screen violence. Russian Education and Society, 47(11), 88-96. https://doi.org/10.1080/10609393.2005.11056932

Frasineanu, E. S. (2018). Management of learning time and free time education for students. RSP, $58,118-127$

Gould, D., \& Carson, S. (2008) Life skills development through sport: Current status and future directions. International Review of Sport and Exercise Psychology, 1(1), 58-78, https://doi.org/10.1080/17509840701834573

Gözel, E. (2010). İlkögretim okulu ogretmenlerinin zaman yonetimi hakkındaki goruslerinin bazı degiskenler acisindan incelenmesi. Muğla Üniversitesi Sosyal Bilimler Enstitüsü Dergisi, $24,67-84$. 
Gumusgul, O. (2013). Avrupa Birligi'ne uye ulkelerde ve Turkiye'de ögrenim goren universite ogrencilerinin zaman yonetimi anlayislarını farkl degiskenler acisindan incelenmesi (pp. 71-73). Yuksek Lisans Tezi, Kutahya: Dumlupinar Universitesi.

Gumusgul, O. (2018). Comparison of time management perception of students studying at department of physical education and sports teaching and program in primary school education. Asian Journal of Education and Training, 4(3). https://doi.org/10.20448/journal. 522.2018.43.224.227

Gurbuz, M., \& Aydin, H. A. (2012). Zaman kavrami ve yonetimi. Kahramanmaras Sutcu Imam Universitesi Sosyal Bilimler Dergisi, 9(2), 1-20.

Hickerson, B. D., \& Beggs, B. A. (2007). Leisure time boredom: Issues concerning college students. College Student Journal, 41(4), 1036-1044.

Isik, U., \& Cengiz, R. (2018). The Relationship between humour styles and five factor personality traits of physical education and sports students. Universal Journal of Educational Research, 6(8), 1811-1818. https://doi.org/10.13189/ujer.2018.060826

Isik, U., \& Demirel, M. (2018). Turkish adaptation of study-leisure conflict scale, its validity and reliability. European Journal of Education Studies, 4(3).

Karaküçük, S. (2008). Rekreasyon: bos zamanları degerlendirme. Ankara: Gazi Kitabevi.

Karasar, N. (2012). Bilimsel arastirma yontemi (21st ed.). Ankara: Nobel Yayin Dagitim.

Lavallee, D., \& Robinson, H. K. (2007). In pursuit of an identity: A qualitative exploration of retirement from women's artistic gymnastics. Psychology Sport and Exercise, 8, 119-141. https://doi.org/10.1016/j.psychsport.2006.05.003

Macquet, A.-C. (2009). Recognition within the decision-making process: A case study of expert volleyball players. Journal of Applied Sport Psychology, 21, 64-79. https://doi.org/ $10.1080 / 10413200802575759$

Misra, R., \& McKean, M. (2000). College students' academic stress and its relation to their anxiety, time management, and leisure satisfaction. American Journal of Health Studies, 16(1), 41-51.

Razali, S. N. A. M., Rusiman, M. S., Gan, W. S., \& Arbin, N. (2018). The impact of time management on students' academic achievement. In Journal of Physics: Conference Series, 995(1), 1-7. https://doi.org/10.1088/1742-6596/995/1/012042

Robinson, J. P., \& Godbey, G. (1999). Time for life: The surprising ways Americans use their time. PA: The Pennsylvania State University Press.

Serdar, E., Demirel, D. H., Demirel, M., \& Cakir, V. O. (2017). The relationship between university students' free time management and academic success. The Online Journal of Recreation and Sport, 6(4). https://doi.org/10.22282/ojrs.2017.22

Stambulova, N., Franck, A., \& Weibull, F. (2012). Assessment of the transition from 
junior-to-senior sports in Swedish athletes. International Journal of Sport and Exercise Psychology, 10(2), 79-95. https://doi.org/10.1080/1612197X.2012.645136

Stebbins, R. A. (2016). In M. Demirel, N. E. Ekinci, U. D. Ustun, U. Isik, O. Gumusgul (Trans.), The Idea of leisure first principles. Ankara: Sports Publishing.

Tanyeri, Y. (2003). Sanat ve spor. Sanat Dergisi, 0(4).

Ustun, U. D. (2013). Beden egitimi ve spor yuksekokulu ogrencilerini rekreatif faaliyetlere katilmaya motive eden faktorlerin arastirilmasi. Yuksek Lisans Tezi. Kutahya: Dumlupinar Universitesi.

Wang, W. C., Kao, C. H., Huan, T. C., \& Wu, C. C. (2011). Free time management contributes to better quality of life: A study of undergraduate students in Taiwan. Journal of Happiness Studies, 12(4), 561-573. https://doi.org/10.1007/s10902-010-9217-7

Yilmaz, S. (2018). Cagdas Turk resminde spor temalı eserler. Yuksek Lisans Tezi, Erzurum: Ataturk Universitesi.

\section{Copyright Disclaimer}

Copyright for this article is retained by the author(s), with first publication rights granted to the journal.

This is an open-access article distributed under the terms and conditions of the Creative Commons Attribution license (http://creativecommons.org/licenses/by/3.0/). 